\title{
PENGARUH MASA KERJA DAN MOTIVASI KERJA TERHADAP KINERJA GURU SEKOLAH DASAR DI DESA SAMUDRA DAN SAMUDRA KULON
}

\author{
Sugito $^{1}$, Y. Suyitno², Kuntoro ${ }^{3}$ \\ ${ }^{1}$ SDN 2 Samudra, Gumelar, Banyumas \\ ${ }^{2,3}$ Magister Pendidikan Dasar, Universitas Muhammadiyah Purwokerto \\ Email: farandsugito@gmail.com; suyitno.y@gmail.com; kuntoro@ump.ac.id
}

\begin{abstract}
This research aims to identify: 1) the influence of working time on teacher performance, 2) the influence of motivation on teacher performance, and 3) the influence of working time and motivation on performance of elementary school teachers in the villages of Samudra and Samudra Kulon. This research is ex-post facto looking for causal relationships, to reveal facts based on measurements of symptoms that have occurred in each respondent. Determination of the sample in this study is a saturated sample, where all members of the population become the object of research. Total population is 50 people. The analysis carried out was a simple and multiple correlation analysis and regression analysis. Respondents in this research have a working time of 2 to 32 years. The results of this research are (1) there is a negative influence on the working time variable on teacher performance; (2) there is a positive influence on the motivation variable on teacher performance; and (3) there is a positive influence on working time and motivation on performance. The effective contribution of working time and motivation to performance are $8.9 \%$ and $18 \%$, respectively. The relative contribution of working time and motivation to performance are $33 \%$ and $67 \%$, respectively.
\end{abstract}

Keywords: working time, motivation and performance, elementary teachers'

Abstrak. Penelitian ini bertujuan untuk mengidentifikasi: 1) pengaruh masa kerja terhadap kinerja guru, 2) pengaruh motivasi terhadap kinerja guru, dan 3) pengaruh masa kerja dan motivasi terhadap kinerja guru Sekolah Dasar di Desa Samudra dan Samudra Kulon. Penelitian ini bersifat ex-post facto yang mencari hubungan kausal, untuk mengungkapkan fakta berdasarkan pengukuran atas gejala yang telah terjadi pada diri masing-masing responden. Penentuan sampel dalam penelitian ini adalah sampel jenuh, dimana semua anggota populasi menjadi objek penelitian. Jumlah populasi adalah 50 orang. Analisis yang dilakukan adalah analisis korelasi dan analisis regresi baik sederhana maupun ganda. Responden dalam penelitian ini memiliki masa kerja antara 2 sampai 32 tahun. Hasil penelitian ini adalah (1) terdapat pengaruh negatif variabel masa kerja terhadap kinerja guru ditunjukkan dengan nilai koefisien korelasi 0,443 dan nilai koefisien regresi -0,398. (2) Terdapat pengaruh positif variabel motivasi terhadap kinerja guru yang ditunjukkan dengan nilai koefisien korelasi 0,496 dan nilai koefisien regresi 0,416. (3) Terdapat pengaruh positif variabel masa kerja dan motivasi terhadap kinerja yang ditunjukkan dengan nilai koefisien determinasi 0,269 dan nilai $\mathrm{F}$ hitung 8,659. Sumbangan efektif masa kerja dan motivasi terhadap kinerja masingmasing adalah $8,9 \%$ dan $18 \%$. Sumbangan relatif masa kerja dan motivasi terhadap kinerja masing-masing adalah $33 \%$ dan $67 \%$.

Kata Kunci : masa kerja, motivasi dan kinerja 


\section{Sugito, Y. Suyitno dan Kuntoro}

\section{Latar Belakang Masalah}

Purnaya (2016 : 3) menyatakan bahwa sumber daya manusia adalah faktor sentral dalam suatu organisasi. Organisasi dibuat berdasarkan berbagai visi untuk kepentingan manusia dimana dalam pelaksanaannya visi tersebut dikelola oleh manusia. Manusia merupakan faktor strategis dalam semua kegiatan organisasi. Manusia dikatakan sebagai sumber daya penting karena bagaimanapun canggihnya teknologi yang ada, manusia merupakan pelaku utama dalam teknologi itu sendiri. Peranan manusia memang tidak dapat digantikan oleh alat yang paling canggih sekalipun. Manusia merupakan faktor terpenting dalam menunjang keberhasilan suatu lembaga atau organisasi. Suryono (2011 : 3) menyatakan bahwa salah satu indikator manusia berkualitas tercermin pada produktifitas, disiplin kerja, keswadayaan, keswakarsaan, kinerja tinggi, dan wawasan masa depan. Pegawai atau karyawan yang memiliki kinerja tinggi akan selalu sadar mengenai tanggung jawabnya.

Motivasi juga dapat meningkatkan kinerja guru selain pengalaman mengajar atau masa kerja. Motivasi merupakan hal yang sangat berperan penting dalam meningkatkan suatu aktifitas kerja seorang guru guna mencapai hasil kinerja yang lebih baik. Guru yang mempunyai motivasi tinggi akan selalu berusaha dengan semaksimal dan sebaik mungkin dalam menyelesaikan setiap pekerjaan yang ditugaskan kepadanya. Motivasi yang tinggi diharapkan dapat dimiliki setiap pegawai sehingga mau bekerja keras dan antusias untuk mencapai produktivitas kerja yang tinggi (Hasibuan, 2002:92). Motivasi kerja merupakan kondisi yang mendorong seseorang untuk melaksanakan suatu kegiatan untuk mencapai tujuan organisasi maupun tujuan individual. Motivasi kerja yang tinggi dalam diri seorang guru akan mendorong semangat kerja untuk dapat menyelesaikan tugas- tugasnya dengan baik dan tepat waktu. Mulyasa (2004:120) berpendapat bahwa para pegawai (guru) akan bekerja dengan sungguh-sungguh apabila memiliki motivasi yang tinggi. Apabila memiliki motivasi yang positif, ia akan memperlihatkan minat, mempunyai perhatian, dan ingin ikut serta dalam suatu tugas atau kegiatan. Guru yang masih kurang berhasil dalam mengajar dikarenakan mereka kurang termotivasi untuk mengajar sehingga berdampak terhadap menurunnya produktivitas atau kinerja guru. Peran kepala sekolah dan pihak lain yang terkait sangat diperlukan untuk dapat memotivasi para guru agar semakin meningkatkan kinerjanya.

Motivasi kerja yang diharapkan dari seorang guru adalah bahwa fungsi dari motivasi tersebut dapat mempengaruhi kinerjanya. Motivasi mempersoalkan bagaimana caranya menumbuhkan gairah serta semangat kerja guru dan karyawan agar mau bekerja keras dan mengembangkan segala kemampuan, pikiran, tenaga, dan keterampilan yang dimiliki untuk mewujudkan tujuan pendidikan. Masa kerja yang cukup dan juga motivasi yang tinggi dari seorang guru diharapkan dapat meningkatkan kinerjanya dalam dunia pendidikan. Kinerja merupakan faktor penting untuk mendukung keberhasilan suatu pekerjaan guru baik dalam kapasitas pribadi maupun sebagai anggota suatu organisasi atau lembaga. Kinerja guru merupakan perwujudan kerja yang dilakukan oleh seorang guru. Kinerja guru yang baik merupakan suatu langkah untuk menuju tercapainya tujuan pendidikan. Mangkunegara (2011:67) mengemukakan kinerja adalah hasil kerja secara kualitas dan kuantitas yang dicapai seseorang dalam melaksanakan tugasnya sesuai dengan tanggung jawab yang diberikan kepadanya.

Kinerja guru adalah hasil kerja yang dicapai guru dalam melaksanakan tugas-tugas yang dibebankan kepadanya. Kinerja guru yang optimal dipengaruhi 
oleh berbagai faktor, baik internal maupun eksternal. Faktor-faktor tersebut antara lain: pengalaman kerja, keterampilan teknis, tingkat pendidikan, gaya kepemimpinan kepala sekolah, motivasi kerja, dan kepuasan kerja. Robbins (2008:184) mengungkapkan bahwa kinerja juga dapat dipengaruhi oleh kemangkiran, komitmen, kompetensi, produktivitas, motivasi, dan kepuasan kerja. Kinerja seorang guru sangat ditentukan oleh adanya motivasi kerja. Motivasi kerja merupakan kekuatan atau sebagai pendorong seseorang untuk melakukan suatu kegiatan yang diwujudkan dalam bentuk perbuatan nyata yaitu dalam bekerja. Semakin tinggi motivasi yang dimiliki dalam diri seorang pegawai, diharapkan akan semakin tinggi pula kinerja yang dihasilkan, sebaliknya semakin rendah motivasi yang dimiliki oleh seorang pegawai maka akan semakin rendah pula kinerja yang dihasilkan.

Suteja (2019 : 74) menyatakan bahwa tugas dan tanggungjawab guru tidak terbatas hanya mendidik, mengajar, membimbing, mengarahkan, melatih, menilai, dan mengevaluasi peserta didik. Tugas dan tanggung jawab guru menyangkut pula sebagai administrator kelas. Guru sebagai administrator kelas pada hakikatnya merupakan jalinan antara ketatalaksanaan bidang pengajaran dan ketatalaksanaan pada umumnya. Guru di sekolah bukan hanya memiliki kewajiban datang untuk mengajar dan setelah selesai kemudian pulang. Guru juga harus menyelesaikan administrasi pembelajaran ataupun administrasi siswa lainnya. Banyaknya tugas tambahan diluar tugas utama guru sebagai pengajar juga menjadi penyebab kurang disiplinnya guru dalam menyelesaikan berbagai administrasi pembelajaran.

Kinerja guru yang belum optimal juga terlihat dari pembuatan data-data sekolah yang masih tertunda-tunda. Hasil dari studi dokumen administrasi dan juga papan informasi di kelas menunjukkan bahwa sebagian guru masih belum memperbarui data-data yang terpajang di dinding kelas ataupun tertulis di buku administrasi. Data-data yang seharusnya sudah diganti atau tidak dipakai masih tertempel di dinding padahal data tersebut harus selalu diperbarui dan disesuaikan dengan keadaan sekarang. Data dinding hanya dianggap sebagai pajangan pelengkap tanpa memperhatikan kebaruan data, sehingga kita tidak bisa mendapatkan data yang sesuai dengan keadaan terbaru.

\section{Masa Kerja}

Oktaviani (2009:102) mengatakan bahwa senioritas atau masa kerja adalah lamanya seorang karyawan menyumbangkan tenaganya pada perusahaan tertentu. Sejauh mana tenaga dapat mencapai hasil yang memuaskan dalam bekerja tergantung dari kemampuan, kecakapan dan ketrampilan tertentu agar dapat melaksanakan pekerjaannya dengan baik. Masa kerja merupakan pengalaman individu yang akan menentukan pertumbuhan dalam pekerjaan dan jabatan. Hamzah B. Uno (2010: 1) mengatakan bahwa guru memiliki peluang besar untuk belajar dari pengalaman mengajarnya di lapangan daripada belajar dari berbagai penelitian dan pendekatan psikologis. Tugas yang dilakukan dalam mengajar setiap hari merupakan sumber pengetahuan bagi guru yang bersangkutan untuk belajar berbagai kekurangan yang nantinya makin lama tugas profesi sebagai seorang guru dapat diperbaiki berdasarkan pengalaman yang telah dilakukannya selama ini.

Faizin dan Winarsih (2008:20) berpendapat bahwa pertumbuhan jabatan dalam pekerjaan dapat dialami oleh seseorang hanya apabila dijalani dengan proses belajar dan pengalaman. Orang yang bersangkutan diharapkan memiliki sikap kerja yang bertambah maju kearah positif dan memiliki kecakapan 


\section{Sugito, Y. Suyitno dan Kuntoro}

(pengetahuan) kerja yang bertambah baik. Seniati (2006:35) mengatakan bahwa masa kerja merupakan komponen yang terdiri dari usia, lama kerja dan golongan kepangkatan.

Masa kerja guru dalam menjalankan tugasnya dapat dihitung semenjak guru tersebut memiliki ijazah formal perguruan tinggi dan telah memiliki ikatan dengan lembaga pendidikan, sekolah atau madrasah. Masa kerja dihitung selama seseorang menjadi guru, tidak dilihat apakah dia direkrut menggunakan ijazah SPG, D1, D2, atau lainnya. Masa kerja guru yang memiliki tingkat pendidikan D2 dan langsung bekerja sampai dengan pensiun diperkirakan mencapai 40 tahun, sedangkan dengan tingkat pendidikan sarjana, magister, dan doktor masih tetap dalam rentang waktu tersebut. Seorang guru dengan ijazah S1 non kependidikan dengan ditambah Akta-IV memiliki masa kerja yang bisa dihitung sejak guru tersebut pertama kali mengajar dengan ijazah S1-nya, walaupun Akta-IV menyusul kemudian sebagai ijazah yang sah mengajar. Pada penelitaian ini, masa kerja guru adalah lamanya waktu yang telah atau pernah dijalani guru selama dia menjadi guru di sekolah.

Made Rida (2013) dalam hasil penelitiannya mengungkapkan bahwa terdapat korelasi yang signifikan antara masa kerja dengan profesionalisme guru sekolah dasar. Hasil penelitian menunjukkan korelasi yang signifikan antara masa kerja dengan profesionalisme guru sekolah dasar. Variabel masa kerja dapat menjelaskan makin tinggi profesionalisme guru sekolah dasar. Temuan tersebut mengindikasikan bahwa masa kerja mempunyai peranan penting dalam meningkatkan profesionalisme guru sekolah dasar.

Secara keseluruhan dapat disimpulkan bahwa masa kerja merupakan tenggang waktu yang digunakan seorang pegawai untuk menyumbangkan tenaganya pada organisasi atau lembaga. Masa kerja akan menghasilkan sikap kerja dan keterampilan kerja yang berkualitas.

\section{Motivasi Kerja}

Muhamad Busro (2018:51) mengatakan bahwa motivasi adalah penggerak dari dalam individu untuk melakukan aktivitas tertentu dalam mencapai tujuan. Motivasi berasal dari kata motif yang dapat diartikan sebagai kekuatan yang terdapat dalam diri individu, yang menyebabkan individu tersebut bertindak atau berbuat. Motivasi adalah rangkaian kegiatan pemberian dorongan, yaitu bukan hanya kepada orang lain tetapi juga kepada diri sendiri. Melalui dorongan ini diharapkan akan dapat bertindak ke arah tujuan yang diinginkan. Uno (2009:42) menyatakan bahwa motivasi tidak dapat diamati secara langsung, tetapi dapat diinterprestasikan dalam tingkah lakunya. Implementasi tersebut dapat berupa rangsangan, dorongan, atau pembangkit tenaga munculnya suatu tingkah laku.

Mangkunegara

(2011:93)

mengatakan bahwa motivasi merupakan dorongan yang timbul pada diri seseorang yang menggerakkan untuk melakukan sesuatu. Guru yang mempunyai motivasi kerja yang tinggi akan setantiasa bekerja keras untuk mengatasi segala jenis permasalahan yang dihadapi dengan harapan mencapai hasil yang lebih baik. Motivasi kerja tidak hanya berwujud kepentingan ekonomis saja, tetapi biasanya juga berbentuk kebutuhan psikis untuk lebih melakukan pekerjaan secara aktif. Dimyati (2006:96) mendefinisikan motivasi sebagai dorongan mental yang menggerakkan dan mengarahkan perilaku manusia. Motivasi sering kali dikatakan menjadi kunci bagi kreativitas kerja. Kreativitas kerja dapat ditingkatkan dengan motivasi kerja yang tinggi, pengetahuan dan keahlian dalam melakukan tugas dan peran positif yang dimiliki seseorang. 


\section{Kinerja}

Prawirosentono (1999:2) mengatakan bahwa kinerja atau performance adalah hasil kerja yang dicapai oleh seseorang atau sekelompok orang dalam suatu organisasi. Pengertian kinerja disini lebih menekankan sebagai hasil atau prestasi yang dicapai oleh seseorang dalam melaksanakan suatu pekerjaan. Hasibuan (2011:94) menyatakan bahwa kinerja seseorang ditunjukkan dengan keseriusanya dalam menyelesaikan tugas-tugas yang dibebankan kepadanya berdasarkan atas kecakapan, pengalaman, kesungguhan serta waktu. Kinerja atau prestasi merupakan gabungan dari tiga faktor yaitu (a) minat dalam bekerja, (b) penerimaan delegasi tugas, dan (c) peran dan tingkat motivasi seorang pegawai.

Mangkunegara

(2011:59)

menyatakan bahwa kinerja (prestasi kerja) adalah hasil kerja secara kualitas dan kuantitas yang dicapai oleh seorang pegawai dalam melaksanakan tugasnya sesuai dengan tanggung jawab yang diberikan. Hussein Fattah (2017:3) mengatakan bahwa kinerja pada dasarnya dapat dilihat dari dua segi yaitu kinerja pegawai (individu) dan kinerja organisasi. Supardi (2014:23) menyatakan bahwa kinerja guru merupakan kemampuan dan keberhasilan guru dalam melaksanakan tugas-tugas pembelajaran. Uno (2014:86) mengatakan bahwa kinerja guru adalah hasil kerja guru yang terefleksi dalam cara merencanakan, melaksanakan dan menilai proses belajar mengajar yang intensitasnya dilandasi oleh etos kerja, serta disiplin profesional dalam proses pembelajaran.

Menurut Didi (2018:27) kinerja guru di dalam organisasi sekolah pada dasarnya ditentukan oleh kemampuan dan kemauan guru dalam ikut serta mendukung proses belajar mengajar. Faktor ini merupakan potensi guru untuk dapat melaksanakan tugas-tugasnya untuk mendukung kebutuhan sarana pendidikan di sekolah. Mangkunegara (2010:62) menyatakan bahwa kinerja yang berkenaan dengan profesi keguruan merupakan perilaku nyata yang ditunjukkan guru pada waktu memberikan pelajaran pada siswanya. Undang-Undang Nomor 14 Tahun 2005 menyatakan bahwa kinerja guru dapat ditunjukkan dari kemampuan guru dalam menguasai kompetensi yang dipersyaratkan, yakni kompetensi pedagogik, kompetensi kepribadian, kompetensi sosial, dan kompetensi profesional

\section{METODE PENELITIAN Pendekatan Penelitian}

Penelitian ini menggunakan pendekatan kuantitatif korelasional. Pendekatan ini termasuk dalam kategori korelasional karena penelitian ini mencari ada tidaknya hubungan antara satu variabel dengan variabel yang lain dan apabila terdapat hubungan maka dicari seberapa jauh hubungan antar variabel tersebut. Penelitian ini menggunakan desain ex post facto. Desain ex post facto dilakukan untuk mengungkap peristiwa yang terjadi dan kemudian merunut ke belakang untuk mengetahui faktor-faktor yang menimbulkan kejadian tersebut tanpa memberikan perlakuan atau manipulasi variabel yang diteliti.

Sugiyono (2016:73) mengatakan bahwa Penelitian ex-post facto adalah suatu penelitian yang dilakukan untuk meneliti peristiwa yang telah terjadi dan kemudian melihat ke belakang untuk mengetahui faktor-faktor yang dapat menimbulkan kejadian tersebut. Penelitian ex post facto sangat tepat untuk menguji pengaruh variabel bebas terhadap variabel tidak bebas. Desain $e x$ post facto bisa dikaji fakta-fakta yang telah terjadi dan dialami responden. Peneltian yang bersifat ex post facto tidak mengadakan perlakuan terhadap subjek penelitian dan tidak mengadakan manipulasi data, melainkan hanya 
menggali fakta-fakta yang peristiwanya telah terjadi dengan menggunakan kuesioner.

Kuesioner yang digunakan
adalah kuesioner yang bisa merefleksikan persepsi responden terhadap seberapa besar pengaruh masa kerja dan motivasi kerja terhadap kinerja guru di wilayah Desa Samudra dan Samudra Kulon. Pendekatan kuantitatif korelasional diharapkan data yang diperoleh dapat diubah dalam bentuk angka dan analisisnya menggunakan statistik korelasional sehingga hasilnya dapat disimpulkan dengan tepat.

\section{Jenis dan Sumber Data}

\section{Data Primer}

Data primer berupa data kuantitaif yang diambil sebagai dasar dalam penentuan latarbelakang masalah dalam penelitian ini. Data primer juga berupa kuesioner yang berisi daftar pertanyaan terstruktur berisi masa kerja dan motivasi serta hubungannya terhadap kinerja guru.

Data Sekunder

Data sekunder merupakan data yang diperoleh tidak langsung. Data sekunder diperoleh peneliti dari dokumen-dokumen dan buku-buku literatur yang memberikan informasi mengenai masa kerja, motivasi, dan kinerja guru di sekolah.

\section{Tempat dan Waktu Penelitian}

Penelitian ini dilaksanakan di wilayah Desa Samudra dan Samudra Kulon, Kecamatan Gumelar, Kabupaten Banyumas, Provinsi Jawa Tengah. Sedangkan waktu penelitian adalah jenjang waktu yang digunakan selama penelitian berlangsung. Penelitian ini dilaksanakan pada bulan April tahun 2019 sampai dengan Juli 2019.

\section{Populasi}

Populasi dalam penelitian ini adalah seluruh guru sekolah dasar yang berada di sekitar wilayah Desa Samudra dan Samudra Kulon. Peneliti melaksanakan survei kepada setiap responden. Survei dilaksanakan karena semua guru sekolah dasar yang ada di wilayah Desa Samudra dan Samudra Kulon dijadikan obyek penelitian.

\section{E. Variabel Penelitian}

Variabel dalam penelitian ini terdiri dari 2 variabel bebas (independent), dan satu variabel terikat (dependent) yaitu:

1. Variabel bebas (independent)

a. Variabel masa kerja yang selanjutnya dalam penelitian ini diberi notasi $X_{1}$.

b. Variabel motivasi kerja yang selanjutnya dalam penelitian ini diberi notasi $\mathrm{X}_{2}$.

2. Variabel terikat (dependent)

Variabel kinerja guru yang selanjutnya dalam penelitian ini diberi notasi Y.

\section{Teknik Pengumpulan Data}

Teknik pengumpulan data pada penelitian ini adalah sebagai berikut:

\section{Kuesioner}

Instrumen yang digunakan dalam penelitian ini adalah kuesioner. Kuesioner berisi data umum responden, masa kerja menjadi guru dan pernyataan untuk memperoleh skor motivasi dan kinerja guru. Kuesioner dibuat berdasarkan kesesuaian antara tingkat atau skala pengukuran dan teknik pengumpulan data. Kuesioner juga dibuat berdasarkan keterkaitan antara responden dengan jawaban yang diberikan. Jenis kuesioner yang diajukan bersifat langsung dan dengan pertanyaan bersifat tertutup. Sifat langsung dan pertanyaan tertutup dimaksudkan untuk memberikan keleluasaan responden memberikan jawaban-jawabannya.

Jawaban yang diberikan oleh responden dalam penelitian ini kemudian diberi skor dengan mengacu pada skala Likert. Sugiyono (2016:103) menyatakan bahwa skala Likert digunakan untuk mengukur sikap, pendapat dan persepsi seseorang atau sekelompok orang tentang fenomena sosial. Proses pengukuran perlu diantisipasi terjadinya kecenderungan responden dalam mengambil option yang di tengah. Pilihan jawaban ganjil seperti lima atau 
tiga perlu digali kecenderungan responden dalam memberikan ketegasan bersikap. Ketegasan bersikap diperlukan untuk menghindari sikap sanksi dengan memberikan pilihan ditengah-tengah antara dua pilihan yang saling bertolak belakang. Setiap responden diminta mengisi item-item dalam instrumen untuk menilai dirinya sendiri dengan skala Likert.

\section{Dokumentasi}

Teknik dokumentasi adalah cara pengumpulan data dengan menggunakan dokumen-dokumen yang berhubungan dengan penelitian. Data dokumentasi dapat mengenai hal-hal atau variabel berupa foto, catatan, transkrip, buku, surat kabar, majalah, prasasti, legger, notulen, rapat agenda, dan lain sebagainya.

\section{Uji Coba Instrumen Penelitian Uji Validitas \\ Uji Validitas Instrumen Pernyataan Variabel Motivasi Kerja}

Hasil output SPSS diperoleh data bahwa korelasi antara ke-30 butir pertanyaan terdapat 5 butir pernyataan dengan skor total kurang dari $\mathrm{r} 0,279$ ( $\left.\mathrm{r}_{\text {hitung }}<\mathrm{r}_{\text {tabel }}\right)$ maka butir tersebut dinyatakan tidak valid, sehingga harus di drop atau dibuang. Sedangkan sisanya 25 butir pernyataan dengan skor total lebih besar dari 0,279 ( $\left.\mathrm{r}_{\text {hitung }}>\mathrm{r}_{\text {tabel }}\right)$ sehingga dinyatakan valid dan dapat dilanjutkan sebagai pernyataan dalam instrumen penelitian.

Uji Validitas Instrumen Pertanyaan Variabel Kinerja Guru

Variabel kinerja guru terdiri dari 30 buah pernyataan sesuai dengan kisi-kisi indikator kinerja yang telah ditentukan. Setiap pernyataan memiliki 5 alternatif pilihan jawaban. Korelasi antara ke-30 butir pertanyaan terdapat 9 butir pertanyaan dengan skor total kurang dari $r$ tabel 0,279 $\left(r_{\text {hitung }}<r_{\text {tabel }}\right)$ maka dinyatakan tidak valid, sehingga semua butir yang tidak valid di drop atau dibuang. Sedangkan sisanya 21 butir pertanyaan dengan skor total lebih besar dari $r_{\text {tabel }} 0,279\left(r_{\text {hitung }}>r_{\text {tabel }}\right)$ dinyatakan valid, sehingga pernyataan-pernyataan tersebut dapat dilanjutkan sebagai pernyataan dalam instrumen penelitian.

\section{Uji Reliabilitas}

Hasil uji reliabilitas dengan SPSS menunjukkan bahwa kuesioner yang terdiri dari variabel motivasi kerja dan kinerja guru, semuanya reliabel karena memiliki koefisien Alpha lebih besar dari 0,70. Kuesioner variabel motivasi memiliki nilai Cronbach Alpha $(\alpha)$ sebesar 0,794 dan lebih besar dari 0,70 sehingga dikatakan reliabel. Kuesioner variabel kinerja memiliki nilai 0,729 dan lebih tinggi dari 0,70 sehingga kuesioner kinerja juga dikatakan reliabel.

\section{Metode Analisis Data \\ Uji Prasyarat (Asumsi Klasik) Uji Normalitas}

Singgih Santoso (2010:44) menjelaskan bahwa uji normalitas data dilakukan untuk mengetahui apakah data berasal dari suatu populasi yang normal. Data yang baik adalah data yang memiliki pola seperti distribusi normal. Asumsi tersebut diuji dengan menggunakan uji Kolmogorof Smirnov dengan menggunakan komputer program SPSS versi 23 for Windows. Dasar pengambilan keputusan dalam uji normalitas ini terlebih dahulu menentukan hipotesis sebagai berikut: a. $\mathrm{Ho}=$ data penelitian memiliki distribusi tidak normal, b. $\mathrm{Ha}=$ data penelitian memiliki distribusi normal. Kriteria pengambilan keputusan dalam Uji Normalitas Kolmogorof Smirnov adalah sebagai berikut: a. Ho diterima dan $\mathrm{Ha}$ ditolak apabila nilai signifikansi (Sig.) > (lebih besar dari) 0,05 yang berarti bahwa data penelitian berdistribusi tidak normal. b. Ho ditolak dan Ha diterima apabila nilai signifikansi (Sig.) < (lebih kecil dari) 0,05 yang berarti bahwa data penelitian berdistribusi normal.

\section{Uji Linearitas}

Uji linearitas bertujuan untuk mengetahui apakah dua variabel mempunyai hubungan yang linear secara 
signifikan atau tidak. Korelasi yang baik seharusnya terdapat hubungan yang linear antara variabel independen (X) dengan variabel terikat (Y). Dasar pengambilan keputusan dalam uji linearitas ini terlebih dahulu dengan menentukan hipotesis sebagai berikut: a. Ho = tidak ada hubungan yang linear secara signifikan antara variabel bebas dengan variabel terikat. $\mathrm{b}$. $\mathrm{Ha}=$ ada hubungan yang linear secara signifikan antara variabel bebas dengan variabel terikat. Kriteria pengambilan keputusan dalam uji linearitas ini adalah sebagai berikut: a. Ho diterima dan Ha ditolak apabila nilai Deviation from Linearity Sig. > (lebih besar dari) 0,05 yang berarti bahwa tidak ada hubungan yang linear secara signifikan antara variabel bebas dengan variabel terikat. b. Ho ditolak dan $\mathrm{Ha}$ diterima apabila nilai Deviation from Linearity Sig. < (lebih kecil dari) 0,05 yang berarti bahwa ada hubungan yang linear secara signifikan antara variabel bebas dengan variabel terikat.

\section{Uji Multikolinearitas}

Uji multikolinearitas digunakan untuk menguji apakah model regresi ditemukan adanya korelasi (hubungan kuat) antar variabel bebas atau variabel independent. Model regresi yang baik seharusnya tidak terjadi korelasi diantara variabel bebas atau tidak terjadi gejala multikolinearitas. Dalam penelitian ini peneliti melakukan uji multikolinearitas dengan melihat nilai tolerance dan VIF menggunakan program SPSS versi 23 for Windows.

Dasar pengambilan keputusan dalam uji multikolinearitas ini terlebih dahulu menentukan hipotesis sebagai berikut: a. Ho = tidak terjadi gejala multikolinearitas dalam model regresi, b. $\mathrm{Ha}=$ terjadi gejala multikolinearitas dalam model regresi. Kriteria pengambilan keputusan pada uji multikolinearitas dengan Tolerance dan VIF adalah sebagai berikut: Pedoman keputusan berdasarkan nilai Tolerance adalah Jika nilai Tolerance lebih besar dari 0,10 maka artinya tidak terjadi multikolinieritas dalam model regresi. Jika nilai Tolerance lebih kecil dari 0,10 artinya terjadi multikolinieritas dalam model regresi. Pedoman keputusan berdasarkan nilai VIF (Variance Inflation Factor) adalah apabila nilai VIF $<10,00$ maka artinya tidak terjadi multikolinieritas dalam model regresi. Apabila nilai VIF > 10,00 maka artinya terjadi multikolinieritas dalam model regresi.

\section{Uji Heteroskedastisitas}

Bertujuan untuk menguji apakah dalam model regresi terjadi ketidaksamaan variance (variasi) dari nilai residual satu pengamatan ke pengamatan yang lain. Jika variance dari nilai residual satu pengamatan ke pengamatan lain bersifat tetap, maka disebut homoskedastisitas, namun jika variance dari nilai residual satu pengamatan ke pengamatan lain berbeda maka disebut heteroskedastisitas.

Dasar pengambilan keputusan dalam uji multikolinearitas ini terlebih dahulu menentukan hipotesis sebagai berikut: a. Ho = tidak terjadi gejala heteroskedastisitas dalam model regresi, b. $\mathrm{Ha}=$ terjadi gejala heteroskedastisitas dalam model regresi. Kriteria pengambilan keputusan dalam uji heteroskedastisitas dengan menggunakan uji glejser adalah apabila nilai signifikansi (Sig.) lebih besar dari 0,05, maka kesimpulannya tidak terjadi gejala heteroskedastisitas dalam model regresi. Apabila nilai signifikansi (Sig.) lebih kecil dari 0,05, maka kesimpulannya terjadi gejala heteroskedastisitas dalam model regresi.

\section{Pengujian Hipotesis}

\section{Analisis Korelasi}

Analisis korelasi adalah studi pembahasan tentang derajat keeratan hubungan antar variabel yang dinyatakan dengan nilai koefisien korelasi. Hubungan antar variabel tersebut dapat bersifat positif atau negatif. Derajat hubungan biasanya dinyatakan dengan huruf " $r$ " atau disebut juga dengan 
koefisien korelasi sampel yang merupakan penduga bagi koefisien populasi. Sedangkan $r^{2}$ atau $r$ square disebut dengan koefisien determinasi (koefisien penentu). Kekuatan korelasi linear antara variabel yang dihubungkan dapat disajikan dengan $r_{x y}$ yang didefinisikan dengan rumus:

$$
\mathbf{r}_{\mathbf{x y}}=\frac{\mathbf{n}\left(\sum \mathbf{X Y}\right)-\left(\sum \mathbf{X}\right)\left(\sum \mathbf{Y}\right)}{\sqrt{\left[\mathbf{n} \sum \mathbf{X}^{2}-\left(\sum \mathbf{X}\right)^{2}\right]\left[\mathbf{n} \sum \mathbf{Y}^{2}-\left(\sum \mathbf{Y}\right)^{2}\right]}}
$$$$
\text { Dasar pengambilan keputusan }
$$

dalam analisis korelasi ini terlebih dahulu menentukan hipotesis sebagai berikut: a. Ho = tidak ada korelasi antara variabel bebas dengan variabel terikat, $b$. $\mathrm{Ha}=$ ada korelasi antara variabel bebas dengan variabel terikat. Kriteria pengambilan keputusan dalam analisis korelasi berdasarkan nilai signifikansi adalah apabila nilai signifikansi $<0,05$ maka terdapat korelasi antar variabel yang dihubungkan. Sebaliknya jika nilai signifikansi $>0,05$ maka tidak terdapat korelasi antar variabel yang dihubungkan. Berdasarkan Nilai $\mathrm{r}_{\text {hitung }}$ (Pearson Correlations) adalah apabila nilai $r_{\text {hitung }}>r_{\text {tabel }}$ maka ada korelasi antar variabel. Sebaliknya jika nilai $r_{\text {hitung }}<$ $\mathrm{r}_{\text {tabel }}$ maka artinya tidak ada korelasi antar variabel.

\section{Analisis Regresi Sederhana}

Regresi dalam penelitian berguna untuk meramalkan atau memprediksi variabel terikat (Y) apabila variabel bebas (X) diketahui. Regresi sederhana dapat dianalisis karena didasari oleh hubungan fungsional atau hubungan sebab akibat (kausal) variabel bebas (X) terhadap variabel terikat $(\mathrm{Y})$. Persamaan regresi sederhana dirumuskan dengan: $\hat{\mathrm{Y}}=\mathrm{a}+$ bX

Dasar pengambilan keputusan dalam analisis regresi sederhana ini terlebih dahulu menentukan hipotesis sebagai berikut: a. Ho = tidak ada pengaruh antara variabel bebas dengan variabel terikat, $\mathrm{b} . \mathrm{Ha}=$ ada pengaruh antara variabel bebas dengan variabel terikat. Kriteria pengambilan keputusan dalam analisis regresi sederhana berdasarkan nilai signifikansi adalah apabila nilai signifikansi $<0,05$ maka terdapat pengaruh antara variabel bebas dan variabel terikat. Sebaliknya jika nilai signifikansi > 0,05 maka tidak terdapat pengaruh antara variabel bebas dan variabel terikat.

\section{Analisis Regresi Ganda}

Riduwan (2008: 152) menyatakan bahwa analisis regresi ganda adalah suatu alat analisis peramalan nilai pengaruh dua variabel bebas atau lebih terhadap variabel terikat untuk membuktikan ada atau tidaknya hubungan fungsi atau hubungan kausal antara dua variabel bebas atau lebih dengan variabel terikat. Persamaan regresi ganda adalah sebagai berikut: $\hat{Y}=a+b_{1} X_{1}+b_{2} X_{2}$

Dasar pengambilan keputusan dalam analisis regresi ganda ini terlebih dahulu menentukan hipotesis sebagai berikut: a. Ho = tidak ada pengaruh secara simultan antara variabel bebas Masa Kerja $\left(\mathrm{X}_{1}\right)$ dan Motivasi $\left(\mathrm{X}_{2}\right)$ terhadap variabel terikat Kinerja (Y), b. $\mathrm{Ha}=$ ada pengaruh secara simultan antara variabel bebas Masa Kerja $\left(\mathrm{X}_{1}\right)$ dan Motivasi $\left(\mathrm{X}_{2}\right)$ terhadap variabel terikat Kinerja (Y). Kriteria pengambilan keputusan dalam analisis regresi ganda berdasarkan nilai signifikansi adalah apabila nilai signifikansi $<0,05$ maka terdapat pengaruh secara simultan antara variabel bebas Masa Kerja $\left(\mathrm{X}_{1}\right)$ dan Motivasi $\left(X_{2}\right)$ terhadap variabel terikat Kinerja (Y). Sebaliknya jika nilai signifikansi $>0,05$ maka tidak terdapat pengaruh secara simultan antara variabel bebas Masa Kerja $\left(\mathrm{X}_{1}\right)$ dan Motivasi $\left(\mathrm{X}_{2}\right)$ terhadap variabel terikat Kinerja (Y).

\section{Koefisien Determinasi $\left(\mathbf{R}^{\mathbf{2}}\right)$}

Koefisien determinasi bermakna sebagai sumbangan pengaruh yang diberikan variabel bebas (X) terhadap variabel terikat (Y). Nilai koefisien determinasi atau $\mathrm{R}$ Square ini berguna untuk memprediksi dan melihat seberapa besar kontribusi pengaruh yang diberikan variabel $X$ secara simultan (bersamasama) terhadap variabel Y. Persyaratan 
yang harus terpenuhi agar kita dapat memaknai nilai koefisien determinasi adalah hasil uji $\mathrm{F}$ dalam analisis regresi linear berganda bernilai signifikan, yang berarti bahwa ada pengaruh variabel $\mathrm{X}$ secara simultan (bersama-sama) terhadap variabel Y. Apabila hasil analisis tidak signifikan, maka nilai koefisien determinasi tidak dapat digunakan atau dipakai untuk memprediksi kontribusi pengaruh variabel $\mathrm{X}$ secara simultan terhadap variabel $\mathrm{Y}$.

\section{Sumbangan Efektif dan Sumbangan Relatif}

Sumbangan efektif (SE) adalah ukuran sumbangan suatu variabel prediktor atau variabel bebas terhadap variabel terikat dalam analisis regresi. Penjumlahan dari sumbangan efektif untuk semua variabel independen adalah sama dengan jumlah nilai yang ada pada koefisien determinasi atau $\mathrm{R}$ square $\left(\mathrm{R}^{2}\right)$. Sumbangan relatif (SR) adalah suatu ukuran yang menunjukkan besarnya sumbangan suatu variabel prediktor terhadap jumlah kuadrat regresi. Jumlah sumbangan relatif dari semua variabel inde penden adalah $100 \%$ atau sama dengan 1. Syarat untuk dapat menghitung SE dan SR adalah dengan memiliki hasil analisis korelasi dan regresi.

\section{HASIL PEMBAHASAN}

\section{A. Deskripsi Data Penelitian}

Data hasil penelitian mengenai masa kerja guru berdasarkan instrumen yang telah dikerjakan oleh para responden, skor masa kerja guru menyebar dari skor terendah (minimum) adalah 2 dan skor tertinggi (maximum) adalah 32. Rentangan skor (range) yang muncul adalah sebesar 30 berasal dari 32 dikurangi 2. Skor rata-rata (mean) sebesar 16,08, nilai tengah (median) adalah 14,5 , data yang paling sering muncul (mode) adalah 11 yaitu muncul sebanyak 4 kali, dan simpangan baku (standart deviation) adalah 8,87.

Sutrisno Hadi (2001 : 12) mengelompokkan kategori dalam penelitian menjadi 3 kategori yaitu tinggi, sedang, dan rendah. Data menunjukkan bahwa sebanyak 20 responden $(40 \%)$ berada pada kategori rendah, 15 responden $(30 \%)$ berada pada kategori sedang, dan 15 responden (30\%) berada pada kategori tinggi. Dari uraian tabel tersebut terlihat bahwa masa kerja guru SD di wilayah Desa Samudra dan Samudra Kulon hampir merata pada setiap kategori.

Hasil rekap instrumen motivasi yang telah disebar dan dikerjakan oleh responden dapat dilihat pada lampiran 20. Instrumen motivasi terdiri dari 25 pernyataan yang diisi oleh responden dengan skala 1 sampai 5. Data hasil penelitian mengenai motivasi guru berdasarkan jawaban instrumen yang telah dikerjakan oleh para responden menyebar dari skor terendah (minimum) adalah 81 dan skor tertinggi (maximum) adalah 120. Rentangan skor (range) yang muncul adalah sebesar 39 berasal dari 120 dikurangi 81. Skor rata-rata (mean) sebesar 103,56, nilai tengah (median) adalah 106,0, data yang paling sering muncul (mode) adalah 107, dan simpangan baku (standar deviation) adalah 9,50. Data kemudian dibagi menjadi 3 kelompok dengan menggunakan rumus interval. Sebanyak 7 responden (14\%) berada pada kategori rendah, 19 responden $(38 \%)$ berada pada kategori sedang, dan 24 responden $(48 \%)$ berada pada kategori tinggi. Dari uraian tabel tersebut terlihat bahwa persentase kinerja terbesar guru SD di wilayah Desa Samudra dan Samudra Kulon berada pada kategori tinggi yaitu sebesar $48 \%$ atau hampir separuh dari total responden.

Data hasil penelitian mengenai kinerja guru berdasarkan jawaban instrumen yang telah dikerjakan oleh para responden menyebar dari skor terendah (minimum) adalah 69 dan skor tertinggi (maximum) adalah 102. Rentangan skor (range) yang muncul adalah sebesar 33 berasal dari 102 dikurangi 69. Skor rata-rata (mean) 
sebesar 87,36, nilai tengah (median) adalah 88,50 , data yang paling sering muncul (mode) adalah 91, dan standar deviasi adalah 7,97. Data kemudian dibagi menjadi 3 kelompok interval. Sebanyak 9 responden $(18 \%)$ berada pada kategori rendah, 22 responden (44\%) berada pada kategori sedang, dan 19 responden (38\%) berada pada kategori tinggi. Dari uraian tabel tersebut terlihat bahwa persentase motivasi terbesar guru SD di wilayah Desa Samudra dan Samudra Kulon berada pada kategori sedang.

\section{Analisis Korelasi}

Nilai koefisien korelasi antara masa kerja $\left(\mathrm{X}_{1}\right)$ dengan motivasi $\left(\mathrm{X}_{2}\right)$ adalah sebesar -0,665. Koefisien korelasi bernilai negatif menunjukkan terjadinya hubungan yang berbalik arah. Hubungan berbalik arah mengandung makna bahwa apabila terjadi peningkatan nilai pada variabel bebas Masa Kerja $\left(\mathrm{X}_{1}\right)$ maka akan menyebabkan penurunan nilai variabel bebas Motivasi $\left(\mathrm{X}_{2}\right)$. Nilai signifikansi sebesar $0,000<0,05$, maka sesuai dengan kriteria pengambilan keputusan adalah $\mathrm{Ho}$ ditolak dan $\mathrm{Ha}$ diterima. Ho ditolak artinya terdapat korelasi antar variabel bebas Masa Kerja $\left(\mathrm{X}_{1}\right)$ dengan variabel bebas Motivasi $\left(\mathrm{X}_{2}\right)$. Interpretasi koefisien korelasi yang dijelaskan oleh Sugiyono (2016:184) bahwa apabila nilai koefisien korelasi berada pada rentang nilai $0,600-0,799$ maka kekuatan korelasi tersebut berada pada level yang kuat.

Nilai koefisien korelasi antara masa kerja $\left(\mathrm{X}_{1}\right)$ dengan kinerja $(\mathrm{Y})$ adalah sebesar -0,443. Koefisien korelasi bernilai negatif menunjukkan terjadinya hubungan yang berbalik arah. Nilai signifikansi sebesar $0,001<0,05$, maka sesuai dengan kriteria pengambilan keputusan adalah Ho ditolak dan $\mathrm{Ha}$ diterima. Ho ditolak artinya terdapat korelasi antar variabel bebas Masa Kerja $\left(\mathrm{X}_{1}\right)$ dengan variabel terikat Kinerja $(\mathrm{Y})$.

Nilai koefisien korelasi antara motivasi $\left(\mathrm{X}_{2}\right)$ dengan kinerja $(\mathrm{Y})$ adalah sebesar
0,496. Koefisien korelasi bernilai positif menunjukkan terjadinya hubungan yang searah antara variabel bebas terhadap variabel terikat. Nilai signifikansi sebesar $0,000<0,05$, maka sesuai dengan kriteria pengambilan keputusan maka Ho ditolak dan Ha diterima.

\section{Analisis Regresi Sederhana \\ a. Analisis Regresi Sederhana Masa Kerja $\left(X_{1}\right)$ dengan Kinerja ( $\left.Y\right)$}

Persamaan regresi yang dihasilkan adalah $\mathrm{Y}=93,767-0,398 \mathrm{X}_{1}$. Uji hipotesis dilakukan dengan cara membandingkan nilai signifikansi (Sig.) dengan probabilitas 0,05 . Nilai signifikansi (Sig.) sebesar 0,001 lebih kecil dari < probabilitas 0,05 , sehingga dapat disimpulkan bahwa Ho ditolak dan Ha diterima. Ho ditolak yang berarti bahwa terdapat pengaruh Masa Kerja $\left(\mathrm{X}_{1}\right)$ terhadap Kinerja (Y). Besarnya nilai $\mathrm{R}$ square adalah 0,196. Sehingga besarnya varians kinerja guru Sekolah Dasar di wilayah Desa Samudra dan Samudra Kulon dipengaruhi atau ditentukan oleh masa kerja guru adalah sebesar $19,6 \%$.

b. Analisis Regresi Sederhana Motivasi $\left(\mathrm{X}_{2}\right)$ dengan Kinerja ( $\mathrm{Y}$ )

Persamaan regresi yang diperoleh adalah $\mathrm{Y}=44,231+0,416 \mathrm{X}_{2}$. Nilai signifikansi (Sig.) sebesar 0,000 lebih kecil dari < probabilitas 0,05 , sehingga dapat disimpulkan bahwa Ho ditolak dan Ha diterima. Ho ditolak yang berarti bahwa terdapat pengaruh Motivasi $\left(\mathrm{X}_{2}\right)$ terhadap Kinerja (Y). Besarnya nilai $\mathrm{R}$ square adalah 0,246. Sehingga besarnya varians kinerja guru Sekolah Dasar di wilayah Desa Samudra dan Samudra Kulon dipengaruhi atau ditentukan oleh motivasi guru adalah sebesar 24,6\%. Hasil ini sesuai dengan apa yang telah diteliti oleh Isroni (2009). Hasil penelitiannya menunjukkan bahwa variabel motivasi kerja mempunyai pengaruh positif dan signifikan terhadap profesionalisme guru SD Negeri di Kecamatan Grabag Kabupaten Magelang. Hasil tersebut diperoleh 
dengan asumsi bahwa faktor profesionalime guru lain dianggap tetap (ceteris paribus).

\section{Analisis Regresi Ganda}

Persamaan regresi ganda dari variabel bebas Masa Kerja $\left(\mathrm{X}_{1}\right)$ dan Motivasi $\left(\mathrm{X}_{2}\right)$ terhadap variabel terikat Kinerja (Y) adalah $\mathrm{Y}=58,905-0,183 \mathrm{X}_{1}+$ $0,303 \quad \mathrm{X}_{2}$. Nilai signifikansi (Sig.) sebesar 0,001 lebih kecil dari < probabilitas 0,05 , sehingga sesuai kriteria pengambilan keputusan yang telah ditentukan dapat disimpulkan bahwa Ho ditolak dan Ha diterima. Ho ditolak berarti bahwa secara simultan terdapat pengaruh yang signifikan antara variabel bebas Masa Kerja $\left(\mathrm{X}_{1}\right)$ dan variabel bebas Motivasi $\left(\mathrm{X}_{2}\right)$ terhadap variabel terikat Kinerja (Y).

\section{Koefisien Determinasi}

Besarnya nilai koefisien determinasi atau R Square adalah sebesar 0,269. Besarnya nilai koefisien determinasi atau R Square ini umunya berkisar antara $0-1$. Nilai $R$ Square 0,269 ini berasal dari pengkuadratan nilai koefisien korelasi atau "R", yaitu 0,519 × 0,519=0,269. Besarnya angka koefisien determinasi R Square adalah 0,269 atau sama dengan 26,9\%. Angka tersebut mengandung arti bahwa variabel Masa Kerja $\left(\mathrm{X}_{1}\right)$ dan variabel Motivasi $\left(\mathrm{X}_{2}\right)$ secara simultan (bersama-sama) berpengaruh terhadap variabel Kinerja (Y) sebesar 26,9\%. Sedangkan sisanya $(100 \%-26,9 \%=$ $73,1 \%$ ) dipengaruhi oleh variabel lain di luar persamaan regresi ini atau variabel yang tidak diteliti.

\section{Sumbangan Efektif (SE) dan Sumbangan Relatif (SR) \\ a. Sumbangan Efektif (SE)}

Untuk menghitung besarnya Sumbangan Efektif (SE) variabel bebas Masa Kerja $\left(\mathrm{X}_{1}\right)$ dan variabel bebas Motivasi $\left(\mathrm{X}_{2}\right)$ menggunakan rumus sebagai berikut:

$\mathrm{SE}_{\mathrm{x}}=$ Beta $_{\mathrm{x}} \mathrm{xr}_{\mathrm{xy}} \mathrm{x} 100 \%$

Besarnya nilai Sumbangan Efektif (SE) variabel Masa Kerja $\left(\mathrm{X}_{1}\right)$ terhadap variabel Kinerja (Y) adalah sebesar 8,9\%. Besarnya nilai Sumbangan Efektif (SE) variabel Motivasi $\left(\mathrm{X}_{2}\right)$ terhadap variabel Kinerja (Y) adalah sebesar $18,0 \%$. Besarnya nilai Sumbangan Efektif (SE) Total variabel Masa Kerja $\left(\mathrm{X}_{1}\right)$ dan Motivasi $\left(\mathrm{X}_{2}\right)$ terhadap variabel Kinerja (Y) adalah sebesar 26,9\%.

\section{b. Sumbangan Relatif (SR)}

Untuk menghitung besarnya Sumbangan RelatiF digunakan rumus:

$\mathrm{SR}(\mathrm{X}) \%=\frac{\mathrm{SE}(\mathrm{X}) \%}{\mathrm{R}^{2}}$

Besarnya nilai Sumbangan Relatif (SR) variabel Masa Kerja $\left(\mathrm{X}_{1}\right)$ terhadap variabel Kinerja (Y) adalah sebesar $33,0 \%$. Besarnya nilai Sumbangan Relatif (SR) variabel Motivasi $\left(\mathrm{X}_{2}\right)$ terhadap variabel Kinerja (Y) adalah sebesar 67,0\%. Besarnya nilai Sumbangan Relatif (SR) Total variabel Masa Kerja $\left(\mathrm{X}_{1}\right)$ dan Motivasi $\left(\mathrm{X}_{2}\right)$ terhadap variabel Kinerja (Y) adalah sebesar $100 \%$.

\section{Analisis Deskriptif Masa Kerja dan Motivasi terhadap Kinerja}

Guru di wilayah Desa Samudra dan Samudra Kulon yang memiliki masa kerja dalam golongan rendah adalah sebanyak 20 orang. Rata-rata masa kerja adalah 7,35 tahun dan rata-rata skor motivasi adalah 110,70. Masa kerja terendah adalah 2 tahun dan tertinggi adalah 11 tahun dengan skor minimal motivasi adalah 96 dan skor maksimal adalah 120. Rata-rata skor kinerja adalah 89,80 dengan skor minimal 71 dan maksimal 102.

Guru di wilayah Desa Samudra dan Samudra Kulon yang memiliki masa kerja kategori sedang adalah sebanyak 15 orang. Rata-rata masa kerja adalah 16,67 tahun dan rata-rata skor motivasi adalah 102,07. Masa kerja terendah adalah 12 tahun dan tertinggi adalah 21 tahun dengan skor minimal motivasi adalah 88 dan skor maksimal adalah 108 . Rata-rata skor kinerja adalah 90,20 dengan skor minimal 78 dan maksimal 102.

Guru di wilayah Desa Samudra dan Samudra Kulon yang memiliki masa kerja tinggi adalah sebanyak 15 orang. 
Rata-rata masa kerja adalah 27,13 tahun dan rata-rata skor motivasi adalah 95,53. Masa kerja terendah adalah 22 tahun dan tertinggi adalah 32 tahun dengan skor minimal motivasi adalah 81 dan skor maksimal adalah 115. Rata-rata skor kinerja adalah 81,27 dengan skor minimal 69 dan maksimal 96.

Data di atas menunjukkan bahwa ratarata skor kinerja guru di wilayah Desa Samudra dan Samudra Kulon cenderung menurun dari masa kerja yang paling rendah ke masa kerja yang paling tinggi. Guru dengan masa kerja rendah memiliki rata-rata skor kinerja sebesar 89,80 . Skor tersebut sedikit lebih rendah dari rata-rata skor kinerja guru yang memiliki masa kerja sedang. Guru dengan masa kerja sedang memiliki skor rata-rata kinerja sebesar 90,20. Skor ratarata untuk guru dengan masa kerja sedang jauh lebih tinggi dari skor ratarata guru dengan masa kerja lama. Skor rata-rata kinerja guru dengan masa kerja lama sebesar 81,27.

Analisis depkriptif di atas hampir sama dengan hasil penelitian yang dilakukan oleh Triyanto dan Rif'ati Dina Handayani (2016) yang menyatakan bahwa melalui wawancara dan pengamatan menunjukkan bahwa guruguru senior, dengan masa kerja lebih banyak dari 25 tahun, mengalami penurunan motivasi. Guru-guru senior umumnya kurang bergairah dalam mengikuti berbagai kegiatan pengembangan. Beberapa guru senior bahkan lebih suka menunggu untuk pensiun daripada bergabung dengan pengembangan profesinya. Sebaliknya, para guru dengan masa kerja kurang dari 25 tahun memiliki motivasi yang lebih tinggi. Mereka memiliki harapan yang lebih besar dan motivasi untuk meningkatkan karier mereka.

\section{Pengaruh Masa Kerja terhadap Kinerja}

Nilai koefisien korelasi antara variabel bebas Masa Kerja $\left(\mathrm{X}_{1}\right)$ dan variabel terikat Kinerja $(\mathrm{Y}) \mathrm{r}_{\text {hitung }}$ adalah $-0,443$.
Nilai tersebut mengindikasikan bahwa keterkaitan hubungan antara variabel bebas Masa Kerja $\left(\mathrm{X}_{1}\right)$ dan variabel terikat Kinerja (Y) berada pada kategori sedang. Adanya hubungan antara variabel bebas Masa Kerja $\left(\mathrm{X}_{1}\right)$ dan variabel terikat Kinerja (Y) ditunjukkan dengan nilai signifikansi sebesar 0,001 yang lebih kecil dari probabilitas 0,05 , Dengan demikian terdapat korelasi atau hubungan antara variabel bebas Masa Kerja $\left(\mathrm{X}_{1}\right)$ dengan variabel terikat Kinerja (Y). Koefisien korelasi bernilai negatif menunjukkan terjadinya hubungan yang berbalik arah.

Analisis regresi dapat ditentukan besarnya pengaruh yang diberikan variabel Masa Kerja $\left(\mathrm{X}_{1}\right)$ guru terhadap Kinerja (Y) guru Sekolah Dasar di Desa samudra dan Samudra Kulon. Persamaan regresi yang dihasilkan adalah $\mathrm{Y}=$ 93,767 - 0,398 $X_{1}$. Persamaan ini dapat diketahui bahwa kinerja guru Sekolah Dasar di Desa samudra dan Samudra Kulon akan tetap 93,767 poin apabila tidak ada peningkatan masa kerja guru. Kinerja guru Sekolah Dasar di Desa samudra dan Samudra Kulon akan berkurang 0,398 apabila masa kerja guru bertambah satu tahun. Apabila masa kerja guru di Desa Samudra dan Samudra Kulon bertambah satu tahun, maka skor kinerja akan menjadi 93,363 pon.

Ada atau tidaknya pengaruh signifikan antara Masa Kerja $\left(\mathrm{X}_{1}\right)$ terhadap Kinerja (Y) dapat dilihat dari nilai signifikansi (Sig.) sebesar 0,001 lebih kecil dari probabilitas 0,05, sehingga dapat disimpulkan bahwa ada pengaruh antara Masa Kerja $\left(\mathrm{X}_{1}\right)$ terhadap Kinerja (Y). Besarnya persentase masa kerja berpengaruh negatif terhadap kinerja guru Sekolah Dasar di Desa Samudra dan Samudra Kulon (tanpa mempertimbangkan variabel lain) dapat dilihat dari koefisien determinasi. Koefisien determinasi adalah kuadrat dari koefisien korelasi yang telah dihasilkan. Besarnya 


\section{Sugito, Y. Suyitno dan Kuntoro}

koefisien korelasi adalah -0.443, sehingga besarnya koefisien determinasi adalah $-0,443 \quad \mathrm{x}-0,443=0,196$. Besarnya persentase pengaruh masa kerja terhadap kinerja guru Sekolah Dasar di Desa samudra dan Samudra Kulon adalah sebesar 19,6\%.

Hasil analisis korelasi dan analisis regresi membuktikan bahwa masa kerja mempengaruhi secara negatif terhadap kinerja guru. Hipotesis pertama yang diajukan dalam penelitian ini bahwa terdapat pengaruh masa kerja terhadap kinerja guru sekolah dasar di Desa Samudra dan Samudra Kulon adalah terbukti.

\section{Pengaruh Motivasi terhadap Kinerja}

Nilai koefisien korelasi antara variabel bebas Motivasi $\left(\mathrm{X}_{2}\right)$ dan variabel terikat Kinerja (Y) adalah 0,496. Nilai tersebut mengindikasikan bahwa antara variabel bebas Motivasi $\left(\mathrm{X}_{2}\right)$ dan variabel terikat Kinerja (Y) memiliki keterikatan hubungan pada kategori sedang. Adanya hubungan antara variabel bebas Motivasi $\left(\mathrm{X}_{2}\right)$ dan variabel terikat Kinerja $(\mathrm{Y})$ ditunjukkan dengan nilai signifikansi sebesar 0,001 yang lebih kecil dari probabilitas 0,05 , maka sesuai dengan kriteria pengambilan keputusan adalah Ho ditolak dan Ha diterima. Ho ditolak artinya terdapat korelasi atau hubungan antara variabel bebas Motivasi $\left(\mathrm{X}_{2}\right)$ dengan variabel terikat Kinerja (Y). Koefisien korelasi antara variabel bebas Motivasi $\left(\mathrm{X}_{2}\right)$ dan variabel terikat Kinerja (Y) bernilai positif menunjukkan terjadinya hubungan yang searah antara variabel Motivasi $\left(\mathrm{X}_{2}\right)$ dan variabel Kinerja (Y).

Berdasarkan analisis regresi dapat ditentukan besarnya pengaruh yang diberikan variabel Motivasi $\left(\mathrm{X}_{2}\right)$ guru terhadap Kinerja (Y) guru Sekolah Dasar di Desa samudra dan Samudra Kulon. Persamaan regresi yang dihasilkan adalah $\mathrm{Y}=44,231+0,416$ $\mathrm{X}_{2}$.. Dari persamaan ini dapat diketahui bahwa kinerja guru Sekolah Dasar di Desa samudra dan Samudra Kulon akan tetap 44,231 poin apabila tidak ada peningkatan masa kerja guru. Kinerja guru Sekolah Dasar di Desa samudra dan Samudra Kulon akan bertambah 0,416 apabila motivasi guru bertambah satu satuan.

Ada atau tidaknya pengaruh antara Motivasi $\left(\mathrm{X}_{2}\right)$ terhadap Kinerja (Y) dapat dilihat dari nilai signifikansi (Sig.) sebesar 0,000 (lebih kecil dari) < probabilitas 0,05 , sehingga dapat disimpulkan bahwa terdapat pengaruh antara Motivasi $\left(\mathrm{X}_{2}\right)$ terhadap Kinerja (Y). Besarnya persentase motivasi mempengaruhi kinerja guru Sekolah Dasar di Desa Samudra dan Samudra Kulon (tanpa mempertimbangkan variabel lain) dapat dilihat dari koefisien determinasi. Besarnya koefisien korelasi adalah 0,496, sehingga besarnya koefisien determinasi adalah 0,496 x $0,496=0,246$. Besarnya persentase pengaruh masa kerja terhadap kinerja guru Sekolah Dasar di Desa samudra dan Samudra Kulon adalah sebesar 24,6\%.

Berdasarkan hasil analisis korelasi dan analisis regresi sederhana antara variabel Motivasi $\left(\mathrm{X}_{2}\right)$ terhadap variabel terikat (Y) membuktikan adanya pengaruh variabel Motivasi $\left(\mathrm{X}_{2}\right)$ terhadap variabel Kinerja (Y). Hipotesis kedua yang diajukan dalam penelitian ini bahwa terdapat pengaruh motivasi terhadap kinerja guru sekolah dasar di Desa Samudra dan Samudra Kulon adalah terbukti.

\section{Pengaruh Masa Kerja dan Motivasi terhadap Kinerja}

Hasil analisis regresi ganda variabel bebas Masa kerja $\left(\mathrm{X}_{1}\right)$ dan Motivasi $\left(\mathrm{X}_{2}\right)$ terhadap variabel terikat Kinerja (Y) menunjukkan bahwa nilai konstanta sebesar 58,905. Angka ini merupakan angka konstan yang mempunyai arti bahwa jika tidak ada Masa Kerja $\left(\mathrm{X}_{1}\right)$ dan Motivasi $\left(\mathrm{X}_{2}\right)$ maka nilai konsisten Kinerja (Y) adalah sebesar 58,905. Koefisien regresi Masa Kerja $\left(\mathrm{X}_{1}\right)$ sebesar -0,183. Koefisien regresi Masa Kerja $\left(\mathrm{X}_{1}\right)$ bernilai minus (-) mengandung pengertian bahwa Masa 
Kerja $\left(X_{1}\right)$ berpengaruh negatif terhadap Kinerja (Y).

Koefisien regresi Motivasi $\left(\mathrm{X}_{2}\right)$ sebesar 0,303. Kerena nilai koefisien regresi bernilai plus (+), maka dengan demikian dapat dikatakan bahwa Motivasi $\left(\mathrm{X}_{2}\right)$ berpengaruh positif terhadap Kinerja (Y). Persamaan regresi ganda dari variabel bebas Masa Kerja $\left(\mathrm{X}_{1}\right)$ dan Motivasi $\left(\mathrm{X}_{2}\right)$ terhadap variabel terikat Kinerja $(\mathrm{Y})$ adalah $\mathrm{Y}=58,905-$ $0,183 \mathrm{X}_{1}+0,303 \mathrm{X}_{2}$.

Dari persamaan $\mathrm{Y}=58,905-0,183 \mathrm{X}_{1}+$ $0,303 \mathrm{X}_{2}$ dapat dijelaskan bahwa apabila masa kerja guru Sekolah Dasar di Desa Samudra dan Samudra Kulon bertambah satu tahun dan skor poin motivasi juga bertambah satu poin, maka nilai kinerja akan menjadi 59,025 poin. Uji signifikansi dilaksanakan dengan membandingkan nilai signifikansi (Sig.) atau nilai probabilitas hasil output Anova. Hasil output Anova menunjukkan nilai signifikansi (Sig.) sebesar 0,001 lebih kecil dari probabilitas 0,05 , sehingga sesuai kriteria pengambilan keputusan yang telah ditentukan dapat disimpulkan bahwa Ho ditolak dan Ha diterima. Ho ditolak berarti bahwa secara simultan terdapat pengaruh antara variabel bebas Masa Kerja $\left(\mathrm{X}_{1}\right)$ dan variabel bebas Motivasi $\left(\mathrm{X}_{2}\right)$ terhadap variabel terikat Kinerja (Y).

Hasil analisis regresi ganda juga menunjukkan besarnya nilai koefisien determinasi antara variabel bebas Masa kerja $\left(\mathrm{X}_{1}\right)$ dan Motivasi $\left(\mathrm{X}_{2}\right)$ terhadap variabel terikat Kinerja (Y) yaitu sebesar 0,269 . Angka tersebut mengandung arti bahwa variabel Masa Kerja $\left(X_{1}\right)$ dan variabel Motivasi $\left(\mathrm{X}_{2}\right)$ secara simultan (bersama-sama) berpengaruh terhadap variabel Kinerja (Y) sebesar 26,9\%. Sedangkan sisanya $(100 \%-26,9 \%=$ $73,1 \%$ ) dipengaruhi oleh variabel lain di luar persamaan regresi ini atau variabel lain yang tidak diteliti. Sumbangan efektif yang diberikan oleh variabel bebas Masa kerja $\left(\mathrm{X}_{1}\right)$ adalah sebesar
$8,9 \%$. Sumbangan efektif yang diberikan oleh variabel bebas Motivasi $\left(\mathrm{X}_{2}\right)$ adalah sebesar 18,0\%. Sumbangan relatif variabel bebas Masa kerja $\left(\mathrm{X}_{1}\right)$ adalah sebesar $33 \%$ terhadap variabel Kinerja (Y). Angka 33\% berasal dari perbandingan sumbangan efektif variabel bebas Masa kerja $\left(\mathrm{X}_{1}\right)$ terhadap persentase total pengaruh dari semua variabel bebas yang diteliti. Sedangkan variabel bebas Motivasi $\left(\mathrm{X}_{2}\right)$ memberikan sumbangan relatif sebesar 67\%. Angka 67\% berasal dari perbandingan sumbangan efektif variabel bebas Motivasi $\left(\mathrm{X}_{2}\right)$ terhadap persentase total pengaruh dari semua variabel bebas yang diteliti.

Berdasarkan penjelasan di atas membuktikan bahwa Masa Kerja $\left(\mathrm{X}_{1}\right)$ dan Motivasi $\left(\mathrm{X}_{2}\right)$ secara simultan (bersama-sama) berpengaruh terhadap Kinerja (Y) guru Sekolah Dasar di Desa Samudra dan Samudra Kulon. Adanya pengaruh variabel Masa Kerja $\left(\mathrm{X}_{1}\right)$ dan Motivasi $\left(\mathrm{X}_{2}\right)$ terhadap variabel terikat (Y) menjelaskan hipotesis ketiga yang diajukan dalam penelitian ini bahwa terdapat pengaruh masa kerja dan motivasi kerja terhadap kinerja guru Sekolah Dasar di Desa Samudra dan Samudra Kulon adalah terbukti. Hasil analisis deskriptif juga menunjukkan bahwa masa kerja baru atau rendah untuk guru Sekolah Dasar di wilayah Desa Samudra dan Samudra Kulon memiliki rata-rata skor kinerja lebih tinggi dibandingkan dengan rata-rata skor kinerja untuk guru yang memiliki masa kerja sedang dan atau lama.

Berdasarkan hasil penelitian, guru-guru di wilayah Desa Samudra dan Samudra Kulon yang memiliki masa kerja lebih lama harus dapat menjadi contoh bagi para guru yang memiliki masa kerja lebih rendah. Adanya indikasi penurunan kinerja seiring dengan bertambahnya masa kerja guru di wilayah Desa Samudra dan Samudra Kulon menjadi cambuk bagi para guru senior. Guru yang masih muda memang 


\section{Sugito, Y. Suyitno dan Kuntoro}

biasanya akan bekerja lebih keras karena memiliki semangat dan juga keinginan kuat untuk dapat menghasilkan kinerja yang maksimal. Namun guru-guru dengan masa kerja yang lama harus dapat membuktikan bahwa pengalaman mengajar yang lebih lama akan menghasilkan kinerja yang maksimal juga. Guru yang memiliki masa kerja lama juga harus selalu meningkatkan kemampuan dalam hal teknologi informasi. Kemampuan ini sangat berguna untuk menunjang kelancaran dan keberhasilan dalam kegiatan belajar mengajar. Kegiatan belajar mengajar hampir sepenuhnya sudah memanfaatkan perkembangan teknologi informasi. Peningkatan kemampuan dalam hal teknologi informasi sudah tidak dapat ditawar lagi.

Sekolah dan para pemangku kebijakan terkait harus mampu mengambil langkah-langkah yang dapat meningkatkan kinerja guru di wilayah lingkungan kerjanya. Salah satu upaya yang dapat dilakukan adalah dengan cara meningkatkan motivasi kerja guru agar mampu mengoptimalkan potensi yang dimilikinya. Motivasi sangat berperan penting dalam pekerjaan sebagai guru. Seorang guru yang sudah memiliki motivasi tinggi akan dapat bekerja dengan baik yang tentu saja juga akan meningkatkan kinerjanya. Sekolah juga harus dapat memfasilitasi penyelenggaraan kegiatan yang dapat meningkatkan kemampuan teknologi informasi. Peningkatan kemampuan teknologi informasi ini ditujukan terutama untuk guru-guru yang belum dapat secara maksimal mampu menggunakan dan memanfaatkan keberadaan teknologi tersebut.

\section{Simpulan}

Tidak ada pengaruh positif masa kerja guru terhadap kinerja guru Sekolah Dasar di wilayah Desa Samudra dan Samudra Kulon. Adapun besarnya varians kinerja guru Sekolah Dasar di wilayah Desa Samudra dan Samudra
Kulon dipengaruhi negatif oleh masa kerja guru adalah 19,6\%.

Ada pengaruh motivasi guru terhadap kinerja guru Sekolah Dasar di wilayah Desa Samudra dan Samudra Kulon. Adapun besarnya varians kinerja guru Sekolah Dasar di wilayah Desa Samudra dan Samudra Kulon dipengaruhi positif oleh motivasi guru adalah sebesar $24,6 \%$.

Ada pengaruh masa kerja dan motivasi guru secara bersama-sama terhadap kinerja guru Sekolah Dasar di wilayah Desa Samudra dan Samudra Kulon. Pengaruh yang diberikan masa kerja dan motivasi guru secara simultan (bersama-sama) terhadap kinerja guru Sekolah Dasar di wilayah Desa Samudra dan Samudra Kulon adalah sebesar 26,9\%. Masa kerja memiliki sumbangan efektif sebesar 8,9\% (sumbangan relatif $33 \%$ ), sedangkan motivasi memiliki sumbangan efektif sebesar $18 \%$ (sumbangan relatif 67\%).

\section{DAFTAR PUSTAKA}

Ahmadiansah, Reza. 2016. Pengaruh Motivasi Kerja Dan Kepuasan Kerja Terhadap Kinerja Guru SMK Muhammadiyah Salatiga. Interdisciplinary Journal of Communication 1(2):223-236.

Ansofino. 2016. Buku Ajar Ekonometrika. Yogyakarta: Penerbit Deepublish.

Arikunto, Suharsimi. 2013. Prosedur Penelitian: Suatu Pendekatan Praktik. Jakarta: Penerbit Rineka Cipta.

Busro, Muhammad. 2018. Teori-teori Manajemen Sumber Daya Manusia. Jakarta: Penerbit Prenadamedia Group.

Fattah, Hussein. 2017. Kepuasan Kerja dan Kinerja Pegawai: Budaya Organisasi, Perilaku Pemimpin dan Efikasi Diri. Yogyakarta: Penerbit Elmatera.

Ghozali, Imam. 2013. Analisis Multivariate dengan Program SPSS. Semarang: BP Undip. 
Hamali, Arif Yusuf. 2019. Pemahaman Praktis Administrasi Organisasi, dan Manajemen : Strategi Mengelola Kelangsungan Hidup Organisasi. Jakarta: Penerbit Prenamedia Group

Ismanto. 2007. Pengaruh Tingkat Pendidikan dan Masa Kerja Terhadap Kompetensi Pedagogik Guru Madrasah Aliyah (MA) di Kudus. Tesis. Program Pascasarjana Universitas Negeri Semarang. Semarang.

Isroni. 2009. Hubungan Motivasi Kerja, Masa Kerja, dan Kesejahteraan Guru dengan Profesionalisme Guru Sekolah Dasar Negeri di Kecamatan Grabag Kabupaten Magelang. Tesis. Program Pascasarjan Universitas Sebelas Maret. Surakarta.

Kementerian Pendidikan Nasional. 2011. Pedoman Pelaksanaan Penilaian Kinerja Guru (PK Guru). Jakarta: Dirjen PMPTK

Kurniawati, Irma Dwi. 2014. Masa Kerja Dengan Jobengagement Pada Karyawan. Jurnal Ilmiah Psikologi Terapan 2(2): 311-324.

Kurniawan, Albert. 2010. Belajar Mudah SPSS untuk Pemula. Yogyakarta: Penerbit Media Kom.

Made Rida, Nyoman Dantes, Kadek Rihendra Dantes. 2013. Hubungan Motivasi Kerja, Masa Kerja dan Kesejahteraan Guru Terhadap Profesionalisme Guru Sekolah Dasar Negeri di Gugus II Kecamatan Sukasada. E-Journal Program Pascasarjana Universitas Pendidikan Ganesha Volume 3 Tahun 2013.

Mangkunegara, Anwar Prabu. 2010. Evaluasi Kinerja SDM. Bandung: Penerbit PT Refika Aditama.

Murwati, Hesti. 2013. Pengaruh Sertifikasi Profesi Guru Terhadap Motivasi Kerja dan Kinerja Guru di SMK Negeri se-Surakarta. Jurnal
Pendidikan Bisnis dan Ekonomi (BISE)1(1):12-21.

Nawari. 2010. Analisis Regresi dengan MS Excell dan SPSS 17. Jakarta: Penerbit PT Elex Media Komputindo.

Permendikbud Nomor 15 tahun 2018 Tentang Pemenuhan Beban Kerja Guru, Kepala Sekolah, dan Pengawas Sekolah. 2 Mei 2018. Jakarta.

Permendiknas Nomor 16 Tahun 2007 Tentang Standar Kualifikasi Akademik dan Kompetensi Guru. 4 Mei 2007. Jakarta.

Pianda, Didi. 2018. Kinerja Guru: Kompetensi Guru, Motivasi Kerja, dan Kepemimpinan Kepala sekolah. Sukabumi: Penerbit CV Jejak.

Purnaya, I Gusti Ketut. 2016. Manajemen Sumber Daya Manusia. Yogyakarta: Penerbit Andi.

Rahardja, Alice Tjandralila. 2004. Hubungan Antara Komunikasi antar Pribadi Guru dan Motivasi Kerja Guru dengan Kinerja Guru SMUK BPK Penabur Jakarta. Jurnal Pendidikan Penabur - No.03 / Th.III / Desember 2004 (hal. 1-21).

Riduwan. 2008. Metode dan Teknik Menyusun Tesis. Bandung: Penerbit Alfabeta.

Robbins, Stephen P \& Judge, Timothy A. 2008. Perilaku Organisasi oleh Diana Angelica, dkk. Jakarta: Penerbit Salemba Empat.

Rusydiati. 2017. Kepuasan Kerja Guru Terhadap Prestasi Kerja Guru Dalam Meningkatkan Mutu Pendidikan di Madrasah. Jurnal Ilmiah Bidang Pendidikan 11(1): 45-54.

Santoso, Singgih. 2010. Statistik Multivariat. Jakarta: Penerbit PT Elex Media Komputindo.

Sarmanu. 2017. Dasar Metodologi Penelitian Kuantitatif, Kualitatif dan Statistika. Surabaya: Penerbit Airlangga University Press. 


\section{Sugito, Y. Suyitno dan Kuntoro}

Sarwono, Jonathan. 2011. Mixed Methods: Cara Menggabung Riset Kuantitatif dan Riset Kualitatif Secara Benar. Jakarta: Penerbit PT Elex Media Komputindo.

Sugiyono. 2016. Metode Penelitian Kuantitatif, Kualitatif, dan $R \& D$. Bandung: Penerbit Alfabeta.

Suryono, Agus. 2011. Manajemen Sumber Daya Manusia : Etika dan Standar Profesional Sektor Publik. Malang: Penerbit Universitas Brawijaya Press.

Suteja, Jaja. 2019. Etika Profesi Keguruan. Yogyakarta: Penerbit Deepublish (Grup Penerbitan CV Budi Utama)

Undang-Undang Nomor 14 Tahun 2005 tentang Guru dan Dosen. 30 Desember 2005. Lembaran Negara
Republik Indonesia Tahun 2005 Nomor 157. Jakarta.

Triyanto, Rif'ati Dina Handayani. 2016. Teacher Motivation Based on Gender, Tenure and Level of Education. The New Educational review.

DOI:

10.15804/tner.2016.45.3.16

Tulus M.A. 1992. Manajemen Sumber Daya Manusia. Jakarta: Penerbit Gramedia Pustaka Utama

Uno, Hamzah B. 2009. Teori Motivasi dan Pengukurannya. Jakarta: Penerbit PT Bumi Aksara.

Uno, Hamzah B. 2014. Teori Kinerja dan Pengukurannya. Jakarta: Penerbit PT Bumi Aksara.

Winardi, J. 2004. Motivasi dan Pemotivasian dalam Manajemen. Jakarta: Penerbit PT Raja Grafindo Persada 